\title{
MOTORIZED ROAD TRANSPORT: ECONOMIC AND ENVIRONMENTAL COSTS - A POLICY ASSESSMENT FRAMEWORK
}

\author{
S. BASBAS ${ }^{1}$, M. PITSIAVA-LATINOPOULOU ${ }^{2} \&$ E. ZACHARAKI $^{3}$ \\ ${ }^{1}$ Department of Transportation \& Hydraulic Engineering, Faculty of Rural \& Surveying Engineering, School of Technology, \\ Aristotle University of Thessaloniki, Greece. \\ ${ }^{2}$ Laboratory of Transportation Engineering, Department of Transport, Infrastructure, Management and Regional Planning, \\ Faculty of Civil Engineering, School of Technology, Aristotle University of Thessaloniki, Greece. \\ ${ }^{3}$ Unit A, Managing Authority of the Operational Programme 'Railways, Airports, Public Transport - RAPT', Ministry of \\ Transport and Communications, Greece.
}

\begin{abstract}
Transport plays an essential role in economic and social development and in the creation of wealth for the societies. At the same time, transport contributes considerably to many environmental problems, e.g. air pollution and noise. According to European Commission's statistics, in the year 2000, the transport sector contributed $29 \%$ of all $\mathrm{CO}_{2}$ emissions in the $\mathrm{EU}$, of which road transport was responsible for $83 \%$. Another serious problem, with environmental and economic impacts, is congestion. Building new transport infrastructure is unlikely to give a reliable solution to any problem and thus the need for new approaches in transport policy has been recognized. In this paper, a policy assessment framework is presented, in order to assist the responsible bodies and policy makers to draw up a strategy for sustainable transport and mobility and to propose some simple measures for tackling the adverse effects of road transport.
\end{abstract}

Keywords: accidents, congestion, climate change, emissions, motorized road transport, noise, sustainability.

\section{INTRODUCTION}

Transport is a mean to an end and not an end in itself. People travel in order to participate in activities (work, education, shopping, recreation, etc.), and goods are transferred in order to meet their mean and final user (production activities or consumers) in all over the world. Thus, access to activities, products and goods is the object that transport system aims to satisfy, using any of the available modes in the appropriate spatial levels, i.e. road and rail typically for urban environment, road, rail, air and maritime for interurban environment (long distance travel).

Motorized road transport gives the higher level of spatial coverage, ensures better connectivity and accessibility, forming in this way an essential element of the daily urban and interurban reality for both passengers and goods. It is a fact that traffic volumes follow an increasing trend worldwide, resulting in serious impacts for human health, environmental and urban quality, development patterns, road conditions and road safety [1-4].

The excessive and continuous growth of road transport during the last 30 years can be attributed to the following factors [4]:

- expanding economies;

- increase in consumer spending power due to increased variety of products and services;

- increase in urbanization, suburbanization and urban sprawl;

- changes in lifestyle patterns due to changes in household structure and participation to work force (i.e. growth of two-worker households), increase of young drivers and elderly drivers, etc.;

- changes in personal travel behavior due to private car oriented travel habits, lack of adequate alternative modes, media influence in forming behavioral travel patterns, increasing childhood dependence on car travel, etc. 
At the same time, access (or accessibility) to activities or products contributes to the level of development for all countries and therefore transport forms main parameter for the socioeconomic growth of regions. The strong correlation between overall gross domestic product (GDP) growth and the expansion of transport infrastructures is well established. This correlation is even stronger in the case of road transport - in many countries the growth exceeds the GDP - as roads still shoulder the greater portion in both passenger and freight transport, remaining the most common form of movement [4].

In order to promote accessibility and mobility for citizens and commodities and reduce the adverse impact of road transport, developed and developing countries are seeking strategies to secure individual mobility and to improve social and ecological conditions in a joint effort and within the same framework. From this consideration, the concept of sustainability arises as a cornerstone in such approaches and become a policy target: the interest is not focused any more to the development of transport systems but to the development of sustainable transport systems [3].

The Commission's White Paper 'European transport policy for 2010: time to decide' underlines the importance and urgency of taking steps in the direction of sustainable future transport systems, taking seriously into account the increased demand for mobility and the desire for a clean environment. Policy makers have to accommodate these conflicting desires by balancing the positive and negative effects of transport, but they need tools in order to do so [1].

But, if the key concept for policies and strategies is 'sustainable transport' and more specifically 'sustainable road transport' a number of issues have to be defined, such as:

- What is sustainable transport?

- What is sustainable road transport?

- Which are the impacts of motorized road transport?

- Which are the components of a sustainable road transport strategy?

- Which are the available for use instruments for a sustainable strategy?

The aim of this paper is to present a framework able to assist their balancing effort, and it builds upon the experience gathered from studies concerning the impacts of great scale transport projects (e.g. the Egnatia motorway in Greece), a number of traffic studies and evaluations for urban centers and of course, it borrows the EU experience in such tools (like the SUMMA project).

\section{BASIC CONCEPTS}

Sustainability is a wide concept that accompanies almost all the functions of the contemporary society, through the meaning of sustainable development. In general terms, sustainable development is the development that meets the needs of the present generations without compromising the ability of future generations to meet their own needs. This definition invokes three sub-objectives, i.e. economic efficiency, ecological stability and social equity. In other words, it refers to achieving economic efficiency through means that secure ecological stability and social equity.

Economic efficiency requires the positive effects on the economy resulting from the development process and the provision of employment and goods. Ecological stability (or environmental sustainability) refers to environmental protection and requires the perseverance of the environmental balance and the prevention of the derangement by human emissions and resource use, in order to guarantee the functional stability of present ecosystem, on local, regional and global level. At the same time, social equity (or social sustainability) requires to meet the social and distributional needs by ensuring a fair distribution of resources and opportunities, poverty reduction, continuous human development, public participation and democratic policy formations. 
Nevertheless, for the transport sector, sustainability can be specified in a much more detailed way. The subject of a number of research activities undertaken in the transport field is the definition and implementation of a sustainable transport system. The Centre for Sustainable Transportation on 1997 proposed: Sustainable transport system is one that:

- allows the basic access needs of individuals and societies to be met safely and in a manner consistent with human and ecosystem health and with equity within and between generations;

- is affordable, operates efficiently, offers choice of transport mode and supports a vibrant economy;

- limits emissions and waste within the planet's ability to absorb them, minimizes consumption of non-renewable resources, reuses and recycles its components and minimizes the use of land and the production of noise [5].

According to the definition adopted by the European Union Minister's of Transport (2001) - ECMT, a sustainable transport system is one that [5-7]:

- allows the basic access and development needs of individuals, companies and societies to be met safely and in manner consistent with human and ecosystem health and promises equity within and between successive generations;

- is affordable, operates fairly and efficiently, offers choice of transport mode and supports a competitive economy as well as balanced regional development.

- limits emissions and waste within the planet's ability to absorb them, uses renewable resources at or below their rates of generation and uses non-renewable resources at or below the rates of development of renewable substitutes while minimizing the impact on land and the generation of noise [5-7].

Despite the differences that are possible based on the above definitions, all of them underline the need for moving under healthy environmental and economic conditions with safety. This remark sets the concept of sustainable mobility, which, within the context of the EXTRA project, was defined as 'A transport system and transport patterns that can provide the means and opportunities to meet economic, environmental and social needs efficiently and equitably, while minimizing avoidable or unnecessary adverse impacts and their associated costs, over relevant space and time scales' [7].

Thus, environmentally sustainable transport is the transport that does not endanger public health or ecosystems and meets the needs for access consistent with: (a) sustainable use of renewable resources at below their rates of regeneration and (b) use of non-renewable resources at below the rates of development of renewable substitutes [2].

The theoretical dimension of sustainable transport and mobility through the various definitions gives the reason for a practical approach: the expected effects of a sustainable transport system in economy, ecology and society. Table 1 summarizes these effects.

An important issue towards the effort for a sustainable transport system is to determine and assess the exact costs imposed by the transport sector. In order to be able to propose concrete strategies, measures and mechanisms for achieving the target, the exact effects of road transport on the economy, the environment and the society (with special emphasis on human health and the daily life of the citizens) should be defined. The following paragraphs provide a comprehensive review in this direction.

\section{TRANSPORT COSTS}

Transport costs are distinguished in two basic categories: internal and external costs. The first category comes from the provision, i.e. construction and maintenance, and use of transport infrastructure. These 
Table 1: The effects of sustainable transport and mobility.

\begin{tabular}{|c|c|}
\hline Sub-objective & Effect \\
\hline Economy & $\begin{array}{l}\text { - Provision of infrastructure for development, expansion of economies and } \\
\text { employment } \\
\text { - Raise revenue for infrastructure and transport facilities setup, operation and } \\
\text { maintenance } \\
\text { - Operation of reliable, cheap, fast and high-volume transport services } \\
\text { - Time savings and reduction of congestion effects } \\
\text { - Creation of sound financial basis for alternative public transport modes, provision } \\
\text { of different transport options }\end{array}$ \\
\hline Environment & $\begin{array}{l}\text { - Reduction of air pollution, contributing to climate stabilization } \\
\text { - Reduction of noise and visual intrusion } \\
\text { - Reduction of health problems associated with transport emissions } \\
\text { - Increase of safety in transport operations } \\
\text { - Efficient land use distribution } \\
\text { - Integration of environmental and economic dimensions in transport and land } \\
\text { use planning and development } \\
\text { - Development of an environmental sensitive strategic framework to support } \\
\text { decision and policy making }\end{array}$ \\
\hline Society & $\begin{array}{l}\text { - Provision of transport services and mobility for all social groups } \\
\text { - Provision of transport services and accessibility for all geographic areas, } \\
\text { withdrawal of regional isolation, opportunities for rationale land use allocation } \\
\text { - Support of development process in territories aiming to provide jobs and welfare } \\
\text { in all social groups } \\
\text { - Provision of reliable public transport services for all and mainly for those } \\
\text { without an alternative }\end{array}$ \\
\hline
\end{tabular}

Source: [3].

costs have to be recovered from the users (e.g. tools) or/and from the public (e.g. state investments) and they determine the economic feasibility of transport projects, considering the demand for individual mobility and the effect of the new infrastructure on this demand. Thus, internal costs form an essential part for demand and supply decision on the transport market [3].

The second category (external costs) refers to the negative side effects of transport systems, such as congestion, accidents, pollution, noise and aesthetic factors, which affect negatively the present and/or future generations. External costs - usually called externalities - are difficult to be measured and thus almost impossible to make road users to pay the exact cost that they cause (internalization of external costs). Despite the fact that transport and development interacts with target the social welfare, the increase of road transport patronage has adverse effects on environmental conditions, with substantial economic impact. Generally, it is possible to distinguish six categories of environmental and economic impacts $[2,3,7-12]$ :

- climate change and air pollution;

- noise;

- congestion;

- accidents; 
- fuel consumption, exhaustion of non-renewable resources;

- landscape and land value effects: visual intrusion and aesthetics.

Table 2 describes the main internal and external costs and gives a policy option for 'making the users to pay' for the transport costs.

Most human exposure to air pollution comes from road traffic. Despite the efforts for improvements in air quality in Europe, about $90 \%$ of the urban population is still exposed to excess ambient levels of several pollutants. Motor vehicles are the main contributors to air pollution in urban areas, with main pollutants being the carbon monoxide and dioxide $\left(\mathrm{CO}, \mathrm{CO}_{2}\right)$, nitrogen oxides $\left(\mathrm{NO}_{\mathrm{x}}\right)$, sulfur dioxide $\left(\mathrm{SO}_{2}\right)$, particulate matter and volatile organic compounds (VOC). In OECD countries, motor vehicles and road traffic are responsible for $89 \%$ of $\mathrm{CO}, 52 \%$ of $\mathrm{NO}_{\mathrm{x}}$ and $44 \%$ of VOC [9].

Table 2: Main internal and external costs: a 'user pays' alternative.

\begin{tabular}{|c|c|}
\hline Costs & 'User pays' option \\
\hline \multicolumn{2}{|l|}{ Internal } \\
\hline $\begin{array}{l}\text { Infrastructure provision: construction } \\
\text { and maintenance }\end{array}$ & $\begin{array}{l}\text { - Use charges } \\
\text { - Fixed charges }\end{array}$ \\
\hline $\begin{array}{l}\text { Equipment provision: construction and } \\
\text { maintenance }\end{array}$ & - Public procurement \\
\hline \multicolumn{2}{|l|}{ External } \\
\hline Congestion & $\begin{array}{l}\text { - Congestion charging } \\
\text { - Parking fees } \\
\text { - Traffic management } \\
\text { - Fuel taxation }\end{array}$ \\
\hline Accidents & $\begin{array}{l}\text { - Road standards } \\
\text { - Speed limits } \\
\text { - Traffic management } \\
\text { - Drivers' education } \\
\text { - Risk-related insurance premiums }\end{array}$ \\
\hline Emissions - pollution & $\begin{array}{l}\text { - Alternative fuels and modes } \\
\text { - Traffic management } \\
\text { - Promotion of public transport } \\
\text { - Urban planning measures (e.g. neotraditional } \\
\text { design, restricted access areas, etc.) } \\
\text { - Use charges }\end{array}$ \\
\hline Noise - nuisance & $\begin{array}{l}\text { - Standards } \\
\text { - Urban planning measures (e.g. neotraditional } \\
\text { design, restricted access areas, etc.) } \\
\text { - Use charges }\end{array}$ \\
\hline $\begin{array}{l}\text { Fuel consumption, exhaustion of } \\
\text { non-renewable resources }\end{array}$ & $\begin{array}{l}\text { - New generation fuels } \\
\text { - Promotion of public transport } \\
\text { - Fuel taxation }\end{array}$ \\
\hline Landscape and land value effects & - Landscape and urban planning measures \\
\hline
\end{tabular}

Source: [3]. 
High concentrations of pollutants and, more generally, high levels of air pollution are responsible for the demission of life quality in cities, the emergence of diseases fluctuating from simple respiratory problems to cancer, the destruction of tropospheric ozone (VOC and $\mathrm{NO}_{\mathrm{x}}$ ) and the increase of the global temperature through the increase in $\mathrm{CO}_{2}$ (greenhouse gas) concentration. There exists strong evidence for a direct link between respiratory problems, especially in children, and residence near busy roads or roads with increased heavy vehicles traffic. Several studies show a correlation between transport-related air pollution and non-fatal health problems such as bronchitis, cardiovascular diseases and asthma. Climate changes will result in more variable and extreme weather conditions, raised sea levels, immersion of lands, expansion of deserts, destruction of biota species and other effects that are not possible to determine at the present [2].

The second effect, noise, is the simplest perceived effect of road transport as people feel a more direct nuisance, and road traffic seems to be the predominant source of human exposure to noise, except for people living in the vicinity of airports and railway lines. Ambient sound levels have increased as a result of the growing number of road trips and vehicle-kilometers traveled and the higher speeds of motor vehicles. It constitutes a serious transport-related problem in terms of being unpleasant and causing health problems such as stress disturbances, cardiovascular diseases and hearing loss. The upper noise levels are determined according to the type of land uses in the adjacent areas, although it is important to mention that levels above $65 \mathrm{~dB}(\mathrm{~A})$ are unacceptable and incompatible with certain land uses, like immiscibly residential areas, hospitals, schools, etc., in developed countries [9].

In Europe, about $17 \%$ of the citizens are exposed to noise levels above this limit, while the respective proportion for Japan is 30\% and for the United States only 7\% [2]. About 65\% of the Europeans (roughly 450 million people) are exposed to noise levels that can cause serious annoyance, speech interference and sleep disturbance. There is a strong impact of noise on mental activities requiring attention, memory and the ability to handle complex analytical problems and projects. Nevertheless, research works about the health impacts of noise show a connection between serious situations like hypertension and ischemic heart diseases and high noise levels.

The next effect, congested road networks, is the contemporary picture of urban centers. The result is increased noise and air pollution levels day by day and loss of time. According to an OECD work, the total cost of traveling is equivalent to almost $7 \%$ in conditions under congestion, while in freeflowing travel it is only $2 \%$. As time loss is the most serious effect of congestion, it is possible to function as the stick and the carrot for leaving private cars home and shifting to alternative modes for the daily travel. Something like this of course presupposes the existence of reliable and adequate public transport services [3].

Concerning road safety, many research works have been undertaken on the valuation of accidents, which corresponds to valuation of human life, the social cost, the labor cost and the suffering that causes a life lost, a temporary or a permanent disability. Unfortunately, as the levels of car ownership and traffic volumes rise, road safety remains in rather low levels and road accidents increase. More specifically, deaths from road accidents have been gradually decreasing, but mortality and injuries remain in high levels. The result is approximately 120,000 deaths and 2.5 million injuries from road accidents per year in Europe. A third of the figures reported for deaths and serious injuries refer to citizens under the age of 25 years and it is estimated that victims die on average 40 years earlier than their life expectancy, putting a significant cost to society in terms of lost productivity, health care costs, pain, suffering and disability. Thus, the external costs of road accidents may amount to as much as $2.5 \%$ of GDP and for this reason governments should implement solid accident prevention policies. This manifests that we should stop to give a monetary value on each human life and to approximate in this way the society's willingness to pay in order to tackle the accidents [3]. 
Fuel consumption puts a strong pressure on both sustainable development and transport. To date, oil and its byproducts remain the main energy source for transport. Oil reserves have started depleting and the renewable substitutes are being developed and brought into use at lower rates, which results in a contradiction with the concepts of sustainability. In addition, the continuous and increased fuel consumption, due to the increased road traffic, causes additional air pollution, with $\mathrm{CO}_{2}$ emissions set to grow by $70 \%$ between 1995 and $2020[2,8,9]$.

Finally, poor urban quality, visual intrusion and aesthetics made people to move out of the city centers. Compact cities reduced. Suburbanization started to gain the residential preferences; urban sprawl forms the new reality and a different picture of the contemporary cities dominated. This resulted in increased and longer motor vehicle trips, as suburban areas are characterized by poor public transport accessibility, land use segregation and demand for the provision of additional road supply.

\section{COSTS AND POLICY ASSESSMENT}

As mentioned earlier, transport operates in a contradictive double way: it is the mean for economic and social development, but it has serious environmental impacts, resulting in a noble economic cost. Transport is characterized as a typical example of public good and market failure. It serves human needs in a unique way, but it is not possible to internalize the environmental and social costs it causes, i.e. users are not paying (or not paying adequately) for the commodity that they use. Regulation and taxation policies may achieve only a partial internalization of some environmental, health and safety effects, but they cannot include the full economic and social cost of noise, air pollution, congestion and accidents. According to ECMT, these costs are equivalent to approximately 5.6\% of GDP for European countries [2, 9-12].

All impacts have a direct or indirect effect on a person's daily life, and more specifically on the commonly perceived nuisance, the health problems that may result, the ability to participate in activities (i.e. to work and produce) and the spatial distribution of these activities (changes in land uses), as presented in Table 3. Some of these effects can be described in monetary terms, corresponding either to the labor lost and or to the expenses for treatment. Some others, and especially those referring to the nuisance, are subjective or rather complex, and thus it is difficult to attribute to them a monetary value [9].

Nevertheless, in order to fight against the adverse side of transport, a comprehensive strategy based on the available policy options should be formed. At the same time, additional expenses should be made with the form of investments. These investments involve both infrastructure and research in the fields of vehicular stock, efficient road and vehicle equipment and alternative energy resources. Thus, the total costs of transport include a negative portion, referring to the direct effect of transport externalities and a positive one, referring to improvements in infrastructure and broadening of the research activities in order to achieve sustainability for the present and future generations [9].

A comprehensive policy assessment framework have to take into account all the parameters presented in Table 3 in order to conclude in decisions regarding the feasibility of a project or the willfulness of implementing a specific policy or regulation, in order to eliminate the environmental problems and maximize the gains in terms of sustainable development and mobility. Observatories of transport impacts are able to inform such decisions through a set of indices, which in their typical form include $[4,11]$ :

- noise levels and population exposed to these levels in various distances;

- atmospheric concentration of $\mathrm{CO}, \mathrm{CO}_{2}, \mathrm{NO}_{\mathrm{x}}$ and $\mathrm{SO}_{\mathrm{x}}$; 


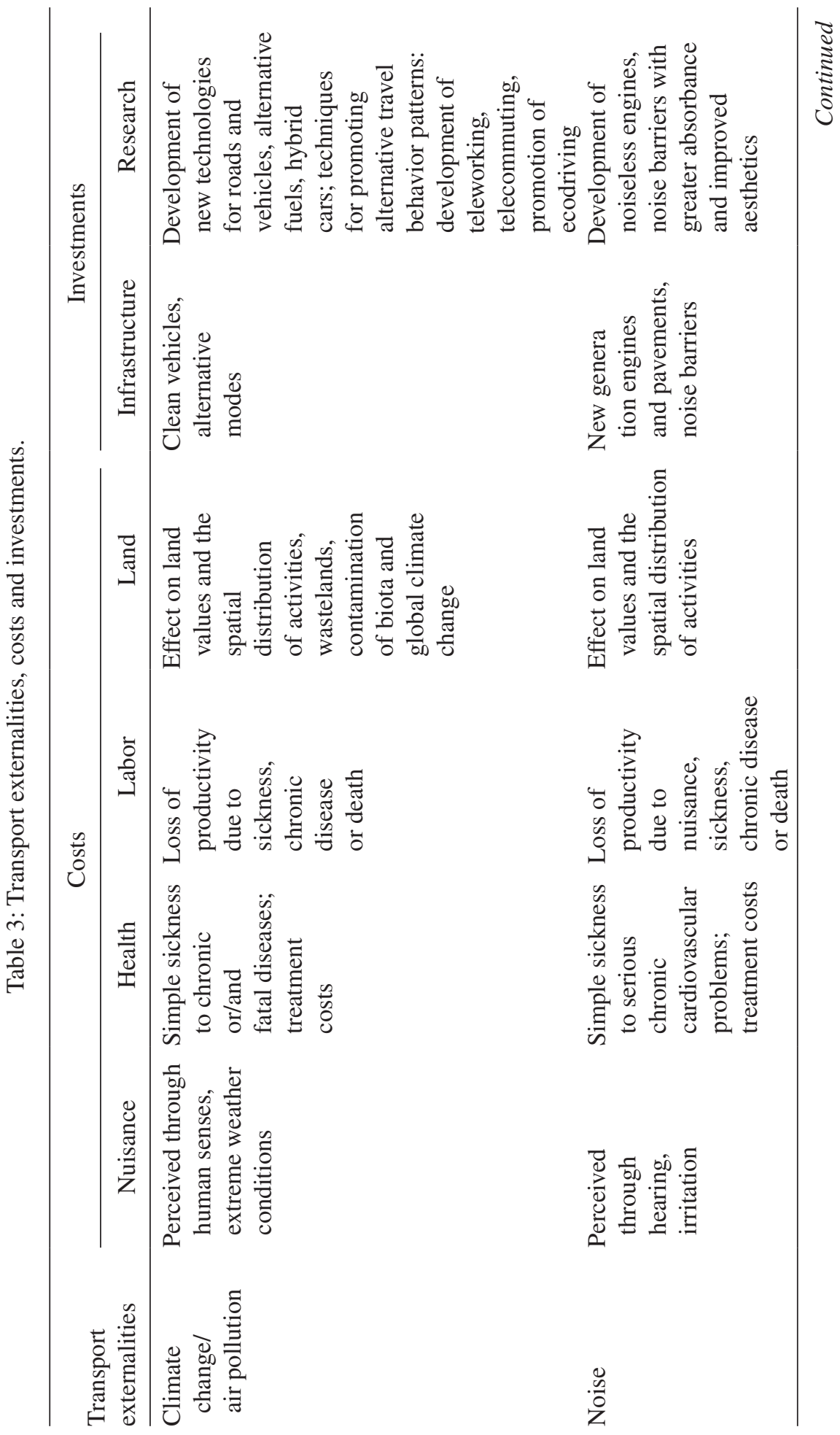




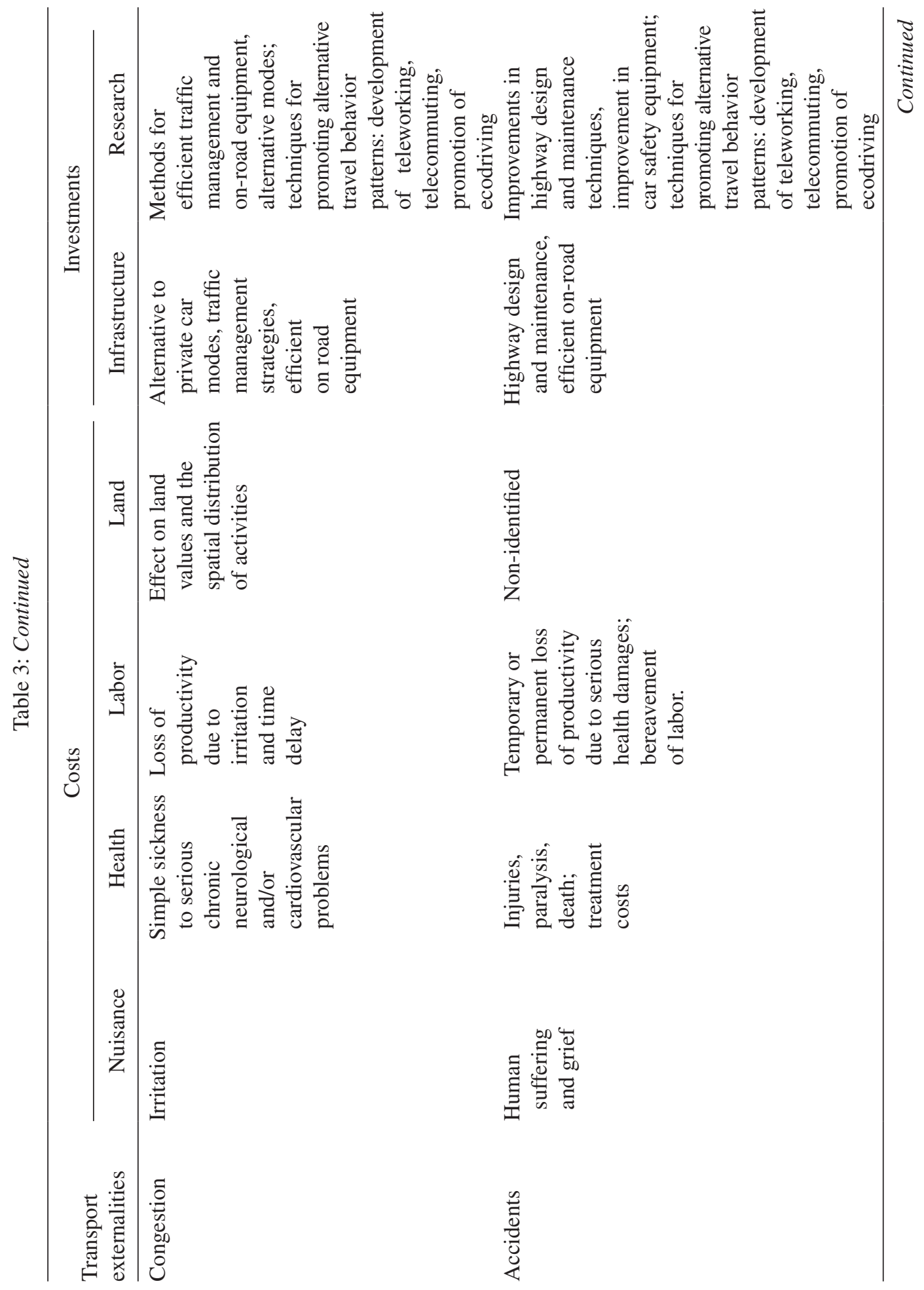




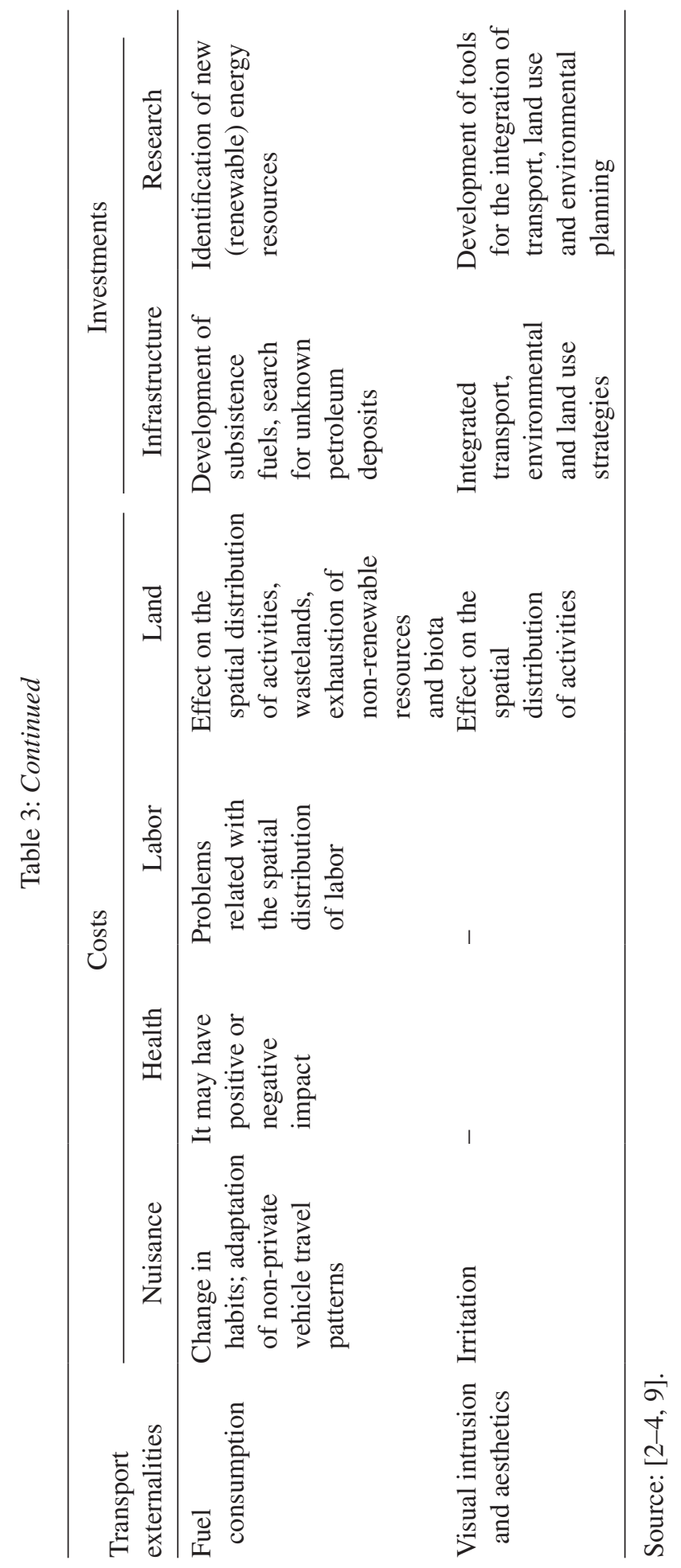


- land use alterations;

- land use values;

- road accidents, traffic volumes, composition and level of service.

The policy and regulatory regimes that are available in order to build sustainable transport strategies, gain revenue, partly internalize the direct and negative costs, gain resources for investments (positive costs) and implement the results of the policy assessment process are synopsized to the following points $[3,10,11,13]$ :

- Regulatory and planning instruments aiming to set standards, restrictions, administrative procedures, etc.

Table 4: Examples of strategic instruments and measures for sustainable transport and mobility.

\begin{tabular}{|c|c|c|}
\hline Target & Instrument & Measure \\
\hline $\begin{array}{l}\text { Discourage motorized } \\
\text { vehicle ownership }\end{array}$ & $\begin{array}{l}\text { Restricting the number of } \\
\text { vehicles and/or new } \\
\text { registrations }\end{array}$ & $\begin{array}{l}\text { - Annual vehicle tax } \\
\text { - Registration tax } \\
\text { - Resale tax } \\
\text { - Auction schemes/competitive bidding } \\
\text { for new licenses } \\
\text { - Licensing car ownership }\end{array}$ \\
\hline $\begin{array}{l}\text { Discourage motorized } \\
\text { vehicle use/encourage } \\
\text { public transport use }\end{array}$ & $\begin{array}{l}\text { Tax charge on vehicle use } \\
\text { Tax/charge on infrastructure use } \\
\text { Restricting access to urban } \\
\text { centers or special areas }\end{array}$ & $\begin{array}{l}\text { - Fuel tax } \\
\text { - Tax on vehicle miles traveled } \\
\text { - Parking fees } \\
\text { - City tools } \\
\text { - Road pricing } \\
\text { - Bridge tools } \\
\text { - Cordon pricing } \\
\text { - Congestion pricing } \\
\text { - Subsidized public transport fees } \\
\text { - Subsidies for public transport networks } \\
\text { - } \text { and operation } \\
\text { - } \text { Tax-deductible public transport } \\
\text { - Park \& Ride schemes } \\
\text { - Investments on alternative and } \\
\text { innovative means of public transport }\end{array}$ \\
\hline $\begin{array}{l}\text { Encourage clean } \\
\text { vehicle technology } \\
\text { use and innovation }\end{array}$ & $\begin{array}{l}\text { Tax/charge on vehicle } \\
\text { purchase/ownership } \\
\text { Taxes/charges on vehicle use } \\
\text { Taxes/charges on infrastructure } \\
\text { use }\end{array}$ & $\begin{array}{l}\text { - Tax differentiations based on } \\
\text { emissions } \\
\text { - Carbon/energy taxes } \\
\text { - Emission fees } \\
\text { - Emission based surcharges } \\
\text { - Subsidies, tax rebates for low-emission } \\
\text { vehicles and technologies. }\end{array}$ \\
\hline
\end{tabular}

Source: $[3,9]$. 
- Cooperation agreements aiming to get all people engaged in a specific issue, to reach a consensus to policy goals and to design voluntary measures to reach these goals.

- Economic instruments aiming to use economic incentives and/or disincentives to pursue a policy goal. It is based on the price mechanism: changing the price or private transport supply and demand, the decisions of the users and providers can be guided in the favorable direction.

- Information instruments aiming to guide in more rational decisions of transport users and suppliers.

Thus, common measures arising from the strategy instruments and the needs of policy assessment are [3]:

- systematic controls of emissions and noise levels; penalties in case of transgressions;

- subsidize the replacement of previous generation (non-environmental friendly) vehicles;

- increase of fuel taxation;

- increase of parking fees;

- stabilization of public transport tickets (in order to increase patronage);

- congestion charging.

Table 4 presents some examples of the strategic instruments and measures that can be applied in order to achieve a specific target. The core targets are: discourage motorized vehicle ownership, discourage motorized vehicle use, encourage public transport use, encourage clean vehicle technology use and innovation. The set of measures proposed in each case is indicative and not exhaustive.

\section{CONCLUSIONS}

Road transport shoulders a great portion of passenger and freight mobility, giving economic development and causing serious environmental problems and noble expenditures. A balance can and should be achieved through the formation of a comprehensive strategy for sustainability, which involves regulatory and planning instruments, cooperation agreements and economic instruments. The gains for sustainable road transport are multifold and involve economic, environmental and social capital. It is obvious that transport planning and the associated decision making needs a shift: people and decision makers should change the way they think and behave. This means that they have to consider a greater variety of impacts in their analysis (direct, indirect and cumulative), considering a broader and innovative range of solutions and using policy will to achieve the targets [14-16].

In this direction, it is crucial to consider such a strategy and invoke the cooperation and complementarity of:

- research activities for the development of new technologies for vehicle engines and equipment, fuels, on-road equipments and pavements;

- investments in new technologies and alternative modes;

- comprehensive assessment of costs and benefits;

- establishment of the necessary structures for the monitoring process of road operation.

It is important to mention once again that investments in research activities are real investments for a sustainable future and a 'positive cost' aiming to realize transport and environmental sustainability for the present and future generations. 


\section{REFERENCES}

[1] European Commission, European Transport Policy for 2010: Time to Decide. COM (2001) 370, White Paper of the Commission of the European Communities, Brussels, 2001.

[2] OECD, Synthesis of OECD work on environment and transport and survey of related OECD, IEA and ECMT activities. Working party on National Environmental Policy. Working Group on Transport, Transport and Environment, Paris, 2002.

[3] UNESCAP, The Challenge: Sustainable Road Transport, United Nations Economic and Social Commission for Asia and Pacific, 2004.

[4] Pitsiava-Latinopoulou, M., Basbas, S. \& Zacharaki, E., An index for impact assessment of a motorway - case study of Egnatia Motorway. Conference Proceedings of 'URBAN TRANSPORT 2002', Seville, Spain, pp. 814-832, 2002.

[5] Centre for Sustainable Transportation (CST), Sustainable Transportation Performance Indicators (STPI) Project, Report on phase 3, 2002.

[6] SUMMA Consortium, Operationalising Sustainable Transport and Mobility: The System Diagram and Indicators, Deliverable 3, Workpackage 2, RAND Europe, Leiden, 2004.

[7] SUMMA Consortium, Setting the Context for Defining Sustainable Transport and Mobility, Deliverable 2, Workpackage 1, RAND Europe, Leiden, 2003.

[8] EXTRA Consortium. Sustainable Mobility - Integrated Policy. EXTRA: Thematic Paper. EXTRA Project was funded by the EC under the Transport RTD Programme of the FP4, 2001.

[9] Maddison, D., Pearce, D., Johansen, O., Calthrop, E., Litman, T. \& Verhoef, E. The True Costs of Road Transport, Blueprint, Earthscan Publications Limited: London, 1996.

[10] UNESC, Overview of Instruments Relevant to Transport, Environment and Health and Recommendations for Further Steps. Synthesis Report, United Nations Economic and Social Council, Economic Commission for Europe, World Health Organization, Regional Office for Europe, 2001.

[11] Delucchi, M.A., The Annualized Social Cost of Motor-Vehicle Use in the U.S., 1990-1991: Summary of Theory, Data, Methods, and Results, UCD-ITS-RR-96-3(1), Institute of Transportation Studies, University of California, Davis, California, 1998.

[12] Poole, F., The transport bill: Part III road charging and workplace parking. Bill 8 of 1999-2000. Research Paper 99/104, Business \& Transport Section, House of Commons Library, London, 1999.

[13] Aristotle University of Thessaloniki - Hellinic Institute of Transport, Observatory for the Spatial Impacts of Egnatia Motorway: A Pilot Application of a System of Indices, Final Deliverable, Egnatia Odos S.A., Thessaloniki, 2001.

[14] Berger, L. et al., Guidance for Estimating the Indirect Effects of Proposed Transportation Projects, Report 403, Transportation Research Board, www.nas.edu/trb, 1998.

[15] Litman, T., Sustainable transportation indicators, VTPI, www.vtpi.org, 2003.

[16] Litman, T. \& Burwell, D., Issues in sustainable transportation. Int. J. Global Environmental Issues, 6(4), pp. 331-347, 2006. doi:10.1504/IJGENVI.2006.010889 